Arredondo-Amezcua, L., S. Martén-Rodríguez, M. Lopezaraiza-Mikel, C. A. Gutiérrez-Chávez, E. Ramírez-Aguirre, R. Sáyago-Lorenzana, M. del Coro-Arizmendi, and M. Quesada. 2018. Hummingbirds in high alpine habitats of the tropical Mexican mountains: new elevational records and ecological considerations. Avian Conservation and Ecology 13(1):14. https://doi.org/10.5751/ACE-01202-130114

Copyright (C) 2018 by the author(s). Published here under license by the Resilience Alliance.

\title{
Hummingbirds in high alpine habitats of the tropical Mexican mountains: new elevational records and ecological considerations
}

\author{
Libertad Arredondo-Amezcua ${ }^{1}$, Silvana Martén-Rodríguez ${ }^{2}$, Martha Lopezaraiza-Mikel $^{3}$, Carlos A. Gutiérrez-Chávez, Erandi \\ Ramírez-Aguirre ${ }^{2}$, Roberto Sáyago-Lorenzana ${ }^{3}$, María del Coro-Arizmendi ${ }^{4}$ and Mauricio Quesada ${ }^{2,5}$ \\ ${ }^{1}$ Centro Regional del Bajío, Instituto de Ecología, A. C., ${ }^{2}$ Laboratorio Nacional de Análisis y Síntesis Ecológica, Escuela Nacional \\ de Estudios Superiores Unidad Morelia, Universidad Nacional Autónoma de México, ${ }^{3}$ Facultad de Desarrollo Sustentable, \\ Universidad Autónoma de Guerrero, ${ }^{4}$ Facultad de Estudios Superiores Iztacala, Universidad Nacional Autónoma de México, \\ ${ }^{5}$ Instituto de Investigaciones en Ecología y Sustentabilidad, Universidad Nacional Autónoma de México
}

\begin{abstract}
Most hummingbird species are distributed in tropical lowlands and mountains with few species reaching the alpine environments of high mountain peaks. Field surveys were conducted in nine alpine sites across four of the highest volcanoes in central Mexico for three years to document hummingbird occurrence, habitat use, and some aspects of behavior. We also searched through historical museum collections and online databases to document early records of hummingbirds in Mexican alpine habitats. In addition, we conducted a search through historical herbarium collections of ornithophilous plant species in alpine habitats, and a literature search on glacier retreats in Mexico to establish past and present elevational limits of alpine vegetation. We recorded the presence of four hummingbird species using floral resources across the nine study sites: Cynanthus latirostris (Broad-billed Hummingbird), Hylocharis leucotis (White-eared Hummingbird), Lampornis clemenciae (Blue-throated Hummingbird), and Selasphorus platycercus (Broad-tailed Hummingbird). The latter two species were recorded frequently throughout the growing season (May-October), whereas C. latirostris was observed on one day in July, and H. leucotis on two days in April and May. Three of the four species were observed foraging from Castilleja tolucensis, an alpine Mexican endemic herb, at $4428 \mathrm{~m}$ above sea level, and all four species foraged from Penstemon gentianoides at the lower alpine sites 3900-4100. At the highest elevations, we observed hummingbirds hovering and perching on rocks while feeding from flowers at ground level. Both male and female of $L$. clemenciae and $S$. platycercus were present at patches of $P$. gentianoides; however, with $S$. platycercus, males accounted for more than $80 \%$ of the individuals observed and more than $95 \%$ of individuals observed at the highest elevations. Additionally, a survey of historical records from museum collections and bird sightings from e-databases revealed only three early records of hummingbirds in alpine sites, with only one observed earlier than 1987. This suggests that hummingbirds were not recorded earlier in alpine habitats because of a lack of sampling. Nevertheless, evidence from glacial retreats and plant distributions along an elevational gradient also indicate that hummingbirds have expanded their elevational range as new habitats have opened up for colonization associated with global climate change. The results reported here are the first records of the four hummingbird species in the Mexican alpine grassland and one of the highest altitudinal records for hummingbirds in North America. We discuss the importance and conservation implications of alpine ecosystems in Mexico as habitats for hummingbirds.
\end{abstract}

\section{Les colibris de milieux alpins élevés dans les montagnes mexicaines tropicales : nouveaux records d'élévation et considérations écologiques}

RÉSUMÉ. La plupart des espèces de colibris sont réparties dans les basses terres et les montagnes tropicales, et quelques espèces atteignent les milieux alpins au sommet de hautes montagnes. Des relevés ont été effectués à neuf sites alpins répartis sur quatre des plus hauts volcans dans le centre du Mexique pendant trois années pour déterminer l'occurrence des colibris, l'utilisation de l'habitat et quelques caractéristiques de leurs comportements. Nous avons aussi consulté des collections muséales historiques et des bases de données en ligne pour répertorier les observations passées de colibris en milieu alpin au Mexique. De plus, nous avons réalisé une recherche de plantes ornithophiles situées en milieu alpin dans des herbiers historiques et une revue de littérature sur le retrait des glaciers au Mexique afin d'établir les limites passées et présentes de la végétation alpine. Nous avons relevé la présence de quatre espèces de colibris utilisant des ressources florales dans nos neuf sites d'étude : Cynanthus latirostris (Colibri circé), Hylocharis leucotis (Saphir à oreilles blanches), Lampornis clemenciae (Colibri à gorge bleue) et Selasphorus platycercus (Colibri à queue large). Les deux dernières espèces ont souvent été repérées durant la saison de croissance des plantes (mai-octobre), tandis que $C$. latirostris a été observé un jour en juillet et $H$. leucotis deux jours en avril et mai. Trois des quatre espèces de colibris ont été observées s'alimentant sur Castilleja tolucensis, une herbe alpine endémique du Mexique, à $4428 \mathrm{~m}$ au-dessus du niveau de la mer, et les quatre espèces se sont alimentées

Address of Correspondent: Silvana Martén-Rodríguez, Laboratorio Nacional de Análisis y Síntesis Ecológica, Escuela Nacional de Estudios Superiores, Unidad Morelia, Universidad Nacional Autónoma de México, Antigua carretera a Pátzcuaro No.8701, Exhacienda de San José de la Huerta, 58190 Morelia, Michoacán, México, smartenr@gmail.com 
sur des Penstemon gentianoides aux sites de plus faible élévation (3 900-4 $100 \mathrm{~m}$ ). Aux sites de plus haute élévation, nous avons observé des colibris faisant du vol stationnaire, se perchant sur des roches et s'alimentant sur des fleurs au niveau du sol. Tant les mâles que les femelles de L. clemenciae et de $S$. platycercus étaient présents dans les groupements de $P$. gentianoides; toutefois, pour $S$. platycercus, les mâles représentaient $80 \%$ des individus observés et plus de $95 \%$ des individus observés aux sites de plus haute élévation. Par ailleurs, la revue des mentions historiques provenant des collections muséales et les observations d'oiseaux tirées des bases de données électroniques ont révélé l'existence de trois mentions antérieures seulement de colibris dans des sites alpins, et d'une unique observation rapportée avant 1987. Ces résultats laissent penser que les colibris n'ont pas été observés en milieu alpin parce qu'il ne s'y était jamais effectué de relevés. Néanmoins, les indices liés au retrait des glaciers et la répartition des plantes le long d'un gradient d'élévation indiquent que l'aire des colibris a gagné du terrain en élévation, à mesure que de nouveaux habitats ont pu être colonisés en raison des changements climatiques planétaires. Nos résultats constituent les premières mentions de quatre espèces de colibris dans les prairies alpines mexicaines et figurent parmi les mentions les plus élevées en altitude pour les colibris d'Amérique du Nord. Nous traitons de l'importance des écosystèmes alpins au Mexique en tant qu'habitat pour les colibris et des répercussions sur leur conservation.

Key Words: Blue-throated Hummingbird; Broad-billed Hummingbird; Broad-tailed Hummingbird; Iztaccíhuatl; La Malinche; Mexican alpine region; Nevado de Toluca; Popocatépetl; White-eared Hummingbird

\section{INTRODUCTION}

Hummingbirds comprise one of the most diverse bird families in the Americas and one of the most important groups of vertebrate pollinators in the Neotropics (Arizmendi and Berlanga 2014). The highest species richness of hummingbirds is in tropical regions, but these birds are also well represented in temperate zones including species with subalpine and alpine distributions (Barrantes 2005, Healy and Calder 2006, Salamanca-Reyes et al. 2008). In fact, the Andean highlands contain the greatest diversity of alpine hummingbirds with at least 24 species, three of which have been reported at 5200 m elevation (Schuchmann 1999, Del Hoyo et al. 2014). Mexico has 58 hummingbird species and most high elevation records are from the subalpine belt between 3000 and $3700 \mathrm{~m}$ in the tropical mountains of the central region of the country (Schondube et al. 2004, Ugalde-Lezama et al. 2010, Pérez et al. 2012, Arbeláez-Cortés and Navarro-Sigüenza 2013, Arizmendi and Berlanga 2014). There is also an alpine record of Selasphorus platycercus in northern Mexico in Cerro el Potosí (Guzmán 1998) and an early record of an indeterminate hummingbird species in the alpine grasslands of Pico de Orizaba above 4000 m.a.s.1. (Swan 1952). Herbarium records of alpine plant species with ornithophilous flowers, i.e., tubular, brightly colored flowers, also suggest the presence of hummingbirds in alpine environments. However, to our knowledge, studies that document hummingbird frequency, behavior, and use of floral resources at high elevation alpine habitats in Mexico are lacking.

The main goal of this study was to determine hummingbird presence and habitat use in the alpine zone of the Trans-Mexican Volcanic Belt (TVB). We also conducted a search through museum and herbarium collections and online databases to determine the past presence of hummingbirds and their plants at the study locations. The observations reported in this study are the highest elevational records for hummingbirds in North America.

\section{METHODS}

\section{Study site}

Fieldwork was conducted in September 2014, May-September 2016 and April-September 2017 at nine study sites located in the TVB, located within the tropical belt between $18^{\circ} 30^{\prime} \mathrm{N}$ and $21^{\circ}$ $30^{\prime} \mathrm{N}$, in four of the highest volcanoes in Mexico: La Malinche (4461 m.a.s.1.), Nevado de Toluca (4690 m), Iztaccíhuatl (5230 m), and Popocatépetl (5465 m; Fig. 1, Appendix 1). Alpine habitats in these mountains occur above timberline between 3900 and $4700 \mathrm{~m}$ (Almeida-Leñero 2007), and have been classified as "alpine grasslands" according to the general classification of Mexican vegetation by Rzedowski (2006). These habitats, are subject to low and fluctuating daily temperatures, high solar irradiance, and periods of intense cloudiness. At $4000 \mathrm{~m}$, mean annual temperature is $5^{\circ} \mathrm{C}$ and mean annual precipitation is 900 $\mathrm{mm}$; on average, there are 200 night frosts per year (Lauer and Klaus 1975, Rzedowski 2006). However, weather conditions are more drastic in the high alpine area $(4500 \mathrm{~m})$, with average temperatures of $2.5^{\circ} \mathrm{C}$ and with 280 night frosts per year (Lauer and Klaus 1975).

Fig. 1. Map of study sites and images of alpine habitats indicating: (a) four volcanoes of the Trans-Mexican Volcanic Belt (TVB) including Nevado de Toluca (NT), Iztaccihuatl (IZ), Popocatepetl (Po), Malinche (Ma) in black triangles; (b) landscape of lower elevation alpine grasslands (3900-4200 m); (c) landscape of high-elevation alpine vegetation (4200-4700 $\mathrm{m})$.

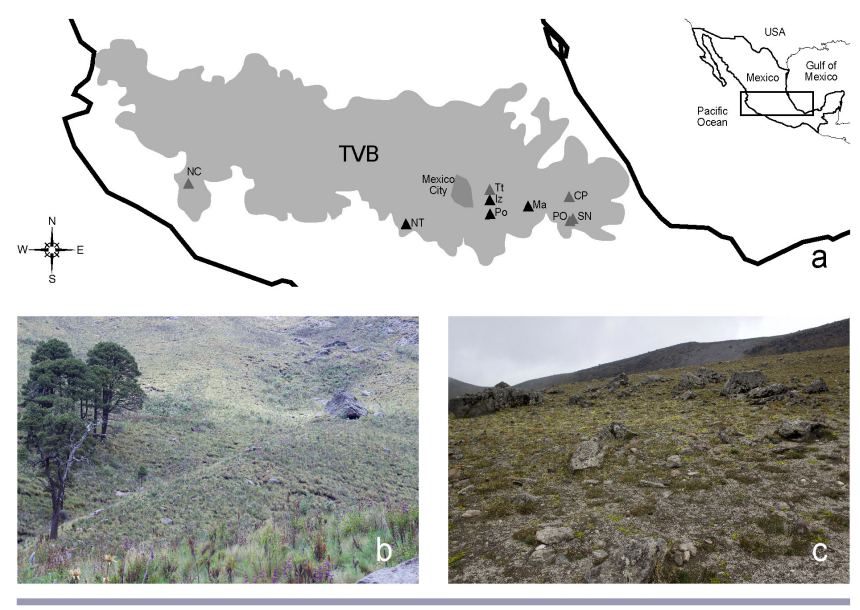

The alpine belt in Mexico includes at least 228 plant species (Victor Steinmann, personal communication) and two major plant communities: a community of dense vegetation dominated by tussock grasses (from timberline to $4200 \mathrm{~m}$ approximately), and a community dominated by small, crawling or cushion- 
Fig. 2. Plant species used by hummingbirds in alpine habitats of the Transmexican Volcanic Belt: (a) Penstemon gentianoides at Iztaccihuatl, (b) Castilleja moranensis at Iztaccihuatl, (c) Castilleja tolucensis at Nevado de Toluca. Photographs by Adolfo López Magaña.

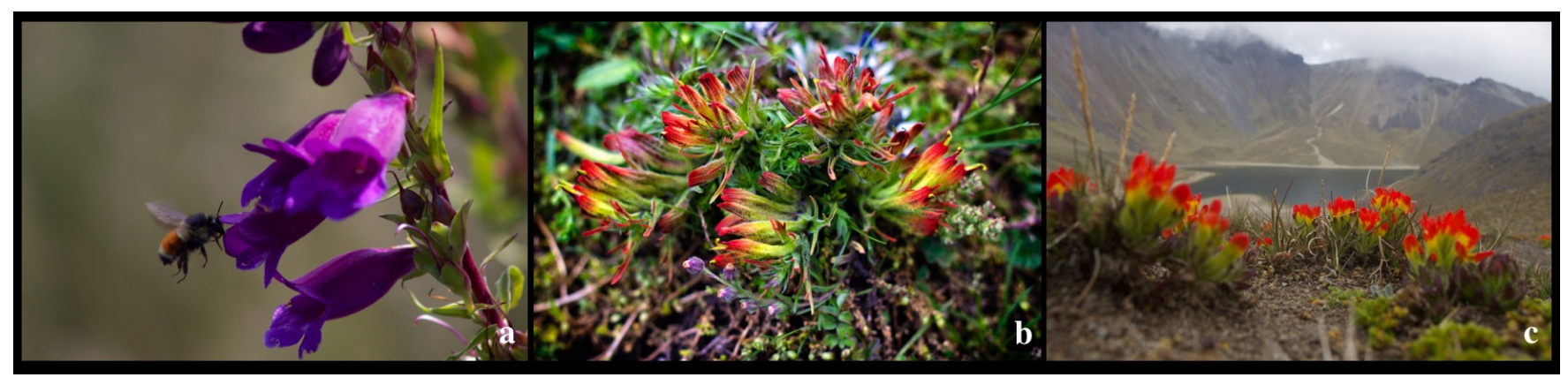

shaped herbs that occur between 4200 and $4700 \mathrm{~m}$ (Fig. 1; Almeida-Leñero et al. 2007, Ramírez-Amezcua et al. 2016). Four of these species in the genus Castilleja have ornithophilous flowers presumably adapted to hummingbird pollination, i.e., tubular, red or brightly colored flowers with abundant dilute nectar and lack of scent (Cronk and Ojeda 2008), and two species in the genus Penstemon have floral traits that attract both hummingbirds and bees (Lara-Rodríguez et al. 2012, Sala-Arcos et al. 2017). We recorded hummingbirds at flowering patches of the three following plant species (Fig. 2): (a) Penstemon gentianoides (H.B. K.) Poir. (Plantaginaceae), a common herb in the low elevation alpine grasslands of the TVB; the species occurs between 3000 to $4200 \mathrm{~m}$ and is also distributed in pine and fir forests below timberline (Rodríguez-Jiménez 2005). It has broad tubular purple flowers with moderate amounts of nectar that are visited by hummingbirds and bees (Sala-Arcos et al. 2017); (b) Castilleja moranensis H.B.K. (Orobanchaceae), an uncommon herb species that forms mats at ground level in pine and fir forests and low elevation alpine communities between 2600 to $3900 \mathrm{~m}$. It has tubular red-yellow flowers that are visited by Hylocharis leucotis and Lampornis clemenciae at one forest location in central Mexico (2700-3000 m; Díaz-Valenzuela 2016); (c) Castilleja tolucensis H. B.K. (Orobanchaceae) an herb that forms large patches at ground level and has a strictly alpine distribution (4000 to $4450 \mathrm{~m})$. It grows on gravel or rocky terrain in slopes of morrenic accumulation in the high alpine plant community (AlmeidaLeñero et al. 2007). It has tubular red-yellow flowers that grow on short stems right above the ground (Rodríguez-Jiménez 2005).

\section{Hummingbird observations, behavior, and resource use}

To document hummingbird presence and habitat use in alpine habitats of central Mexico, we conducted observations of hummingbirds at 26 flower patches of $C$. moranensis $(\mathrm{N}=2$ patches), C. tolucensis $(\mathrm{N}=13)$, and $P$. gentianoides $(\mathrm{N}=11)$. We recorded the presence of hummingbirds and floral visitation through direct observation and video camera recordings for periods of 1-4 hrs throughout the day (8:00 and 18:00 h). Video recordings were taken with SONY camcorders in two ways: (1) focal observations where cameras were set up in front of individual plants or small flower patches for 2-4 hrs, (2) observations where a human observer with video cameras followed the hummingbirds until a clear video of the species was obtained. We implemented the second method after finding that visitation rates to individual flowers recorded in stationary cameras were extremely low, and because clear images were required for bird identification. We also took photographs of the hummingbirds when conducting direct observations. The number of observation hours and flower patches observed at each volcano are listed in Appendix 1. To identify species observed in videos, photographs, or directly in the field, we used the bird field guides by Arizmendi and Berlanga (2014) and Parque Nacional IztaPopo (2015). To elucidate the dubious identity of some of the birds recorded in videos, in August 2016 we selected two patches of Penstemon flowers at the Iztaccíhuatl volcano at $4000 \mathrm{~m}$, and set up two mist nets between 8:00 and 14:00 hrs at the edge of each flower patch. We took pictures of the hummingbirds caught in the nets and recorded species and gender.

While conducting observations, we recorded and classified the behavior of each hummingbird into one of the following categories: perching, foraging, flying, defending a patch (from other hummingbirds or bees), and courtship behavior. To document the environmental conditions under which hummingbirds were active at the study sites, we consulted temperature and humidity data by sampling day, recorded at the atmospheric observatory Altzomoni of the University Network of Atmospheric Observatories, Universidad Nacional Autónoma de México (UNAM), at $3985 \mathrm{~m}$ in Iztaccíhuatl (http://www.ruoa. unam.mx/index.php?page=ALTZ). We report minimum and maximum temperatures recorded between 8:00 and 18:00 hrs across the study period.

\section{Historical records of birds, plants, and glaciers}

To determine if the study species had been recorded earlier in alpine habitats in Mexico, we conducted a search of specimens in the Collection of Birds of Facultad de Ciencias (Facultad de Ciencias 2015) and the National Collection of Birds of Instituto de Biología, UNAM (Unidad de Informática para la Biodiversidad 2007; this later collection dates back to 1929 and has a representation of $90 \%$ of Mexican bird species). To assess if the past absence of the study species in alpine habitats was due to the general absence of bird collections at those sites, we also surveyed the historical records of four species that are common 
Table 1. Number of female (F) and male (M) hummingbirds observed at alpine sites of four volcanoes of the Transmexican Vocanic Belt during 2014-2017. Numbers in parentheses indicate additional individuals recorded only from bird calls.

\begin{tabular}{|c|c|c|c|c|c|c|c|c|c|}
\hline \multirow[t]{2}{*}{ Site } & \multirow[t]{2}{*}{ Plant species } & \multirow{2}{*}{$\begin{array}{l}\text { Elevational } \\
\text { range }(\mathrm{m})\end{array}$} & \multirow{2}{*}{$\begin{array}{c}\text { C. latirostris } \\
\mathrm{M} \\
\end{array}$} & \multirow{2}{*}{$\begin{array}{c}\text { H. leucotis } \\
\mathrm{M}\end{array}$} & \multicolumn{2}{|c|}{ L. clemenciae } & \multirow[b]{2}{*}{$\operatorname{Indet}^{\dagger}$} & \multicolumn{2}{|c|}{ S. platycercus } \\
\hline & & & & & $\mathrm{F}$ & M & & $\mathrm{F}$ & $\mathrm{M}$ \\
\hline Popocateptl & P. gentianoides & $3900-4050$ & & & & & 1 & 1 & 2 \\
\hline \multirow[t]{3}{*}{ Iztaccíhuatl } & C. moranensis & $3900-3950$ & & & & & 2 & 1 & 1 \\
\hline & C. tolucensis $^{\ddagger}$ & $4050-4450$ & & 2 & & 2 & $1(5)$ & 1 & $6(2)$ \\
\hline & P. gentianoides & $3900-4080$ & 1 & & & 1 & 5 & 4 & $10(4)$ \\
\hline Nevado Toluca & C. tolucensis & $4150-4350$ & & & 1 & & & & 11 \\
\hline \multirow[t]{2}{*}{ La Malinche } & C. tolucensis & $4100-4450$ & & & & & $2(1)$ & & $4(1)$ \\
\hline & P. gentianoides & $3900-4100$ & & & & & & & 2 \\
\hline Total & & & 1 & 2 & 1 & 3 & $11(6)$ & 7 & $36(7)$ \\
\hline
\end{tabular}

Indet. refers to individuals whose gender could not be determined in the field.

*All hummingbird species at this site were observed foraging at $4428 \mathrm{~m}$.

in Mexican alpine grasslands: Xenospiza baileyi, Junco phaeonotus, Oriturus superciliosus, and Diglossa baritula. Additionally, we searched through the e-Bird database (https:// ebird.org/explore) in bird species maps and lists of the four target volcanoes and the mountains above $4000 \mathrm{~m}$ in the TVB: Telapón (4000), Tláloc (4120 m), Cofre de Perote (4250), Nevado de Colima (4240), Sierra Negra (4580), and Pico de Orizaba (5610). We used the geographic coordinates of each hummingbird record to search for the elevation of the site in Google Earth. To ensure that geographic coordinates corresponded with the study site, we searched for distribution and habitat information on the bird species included on each bird list. We disregarded questionable records when there was no correspondence between the alleged geographic location/habitat and the bird species present at the site, e.g., records of hummingbird species in the same list as forest birds like woodcreepers recorded at a presumed elevation of 4200 $\mathrm{m}$, well above timberline.

To investigate associations with flower availability and determine if plants used by hummingbirds were historically present at the highest mountains, we conducted an herbarium survey of the six ornithophilous plant species including: ENCB (Escuela Nacional de Ciencias Biológicas del Instituto Politécnico Nacional), IBUG (Instituto de Botánica de la Universidad de Guadalajara), IEB (Instituto de Ecología - Centro Regional del Bajío), FMCE (Facultad de Ciencias de la Universidad Nacional Autónoma de México), MEXU (Instituto de Biología de la Universidad Nacional Autónoma de México), and XAL (Instituto de Ecología) Mexican herbaria, and MSC (Michigan State University Herbarium). To relate the presence of hummingbirds with recent changes in the extent of suitable habitats for plant growth at the high limits of alpine vegetation, we searched the literature for information on the range of elevations occupied by glaciers in Mexican volcanoes from the end of the Little Ice Age to the present time.

\section{RESULTS}

\section{Hummingbird observations and resource use}

We observed four species of hummingbirds visiting alpine flowers across the nine study sites: Cynanthus latirostris (Swainson 1827, Broad-billed Hummingbird; Appendix 2), Hylocharis leucotis
(Vieillot 1818, White-eared Hummingbird; Appendix 3), Lampornis clemenciae (Lesson 1829, Blue-throated Hummingbird; Appendix 4, 5), and Selasphorus platycercus (Swainson 1827, Broad-tailed Hummingbird; Appendices 6, 7, 8). Selasphorus platycercus and $L$. clemenciae were observed visiting flowers of $P$. gentianoides in the low alpine grasslands (May-September 2014, 2016-2017) and flowers of $C$. tolucensis in the xerophytic zone of cushion-shaped herbs near the highest elevational limits of vegetation (up to $4428 \mathrm{~m}$ in Iztaccihuatl, May-July 2016-2017; Table 1). Cynanthus latirostris was observed once in July 2016 visiting Penstemon flowers in the alpine grasslands, while $H$. leucotis males were observed twice in May 2016 and April 2017 feeding from $C$. tolucensis at the highest study site in Iztaccíhuatl (Table 1).

\section{Hummingbird behavior}

The two most commonly observed species, $L$. clemenciae and $S$. platycercus, were active throughout the day during sunny and cloudy weather at temperatures ranging from $3{ }^{\circ} \mathrm{C}$ to $13{ }^{\circ} \mathrm{C}$. The main behaviors displayed by different individuals of each species are listed in Table 2. Territorial behavior was observed both in $L$. clemenciae and $S$. platycercus, but the dominance hierarchy changed depending on the floral resource. In 2016 and 2017 S. platycercus was dominant at all sites of $P$. gentianoides, chasing L. clemenciae intruders away. However in 2016, male individuals of $S$. platycercus foraged by sneaking into a $C$. tolucensis patch defended by L. clemenciae in Iztaccíhuatl (Appendix 1:Izta 4). Males of both species were also recorded perching on branches, calling, and apparently watching/defending their territories. In this case, the hummingbird perched on a high branch within a patch of $P$. gentianoides or on a large rock in a field of Castilleja tolucensis, and moved its head in different directions; occasionally, the hummingbird chased other hummingbirds that approached the flowers. Hummingbirds did not chase bumblebees that were also frequent visitors to Penstemon flowers. In addition, we observed $H$. leucotis and $S$. platycercus perching on rocks or on the ground while feeding from $C$. tolucensis flowers at the highest alpine sites; we also observed $L$. clemenciae perching on branches while feeding on flowers of P. gentianoides at Iztaccihuatl.

Overall, S. platycercus females were observed less frequently than males (16\% of all individuals) and they were mostly found in the 
Table 2. Behavioral observations of four hummingbird species studied at four volcanoes of the Transmexican Volcanic Belt in 2014 2017. Values indicate the number of times individuals of each species were observed performing one of the six listed behaviors.

\begin{tabular}{|c|c|c|c|c|c|c|c|}
\hline \multirow[t]{2}{*}{ Behavior } & \multirow{2}{*}{$\frac{\text { C. latirostris }}{\mathrm{M}}$} & \multirow{2}{*}{$\frac{\text { H. leucotis }}{\mathrm{M}}$} & \multicolumn{2}{|c|}{ L. clemenciae } & \multirow[b]{2}{*}{ Indet $^{1}$} & \multicolumn{2}{|c|}{ S. platycercus } \\
\hline & & & $\mathrm{F}$ & $\mathrm{M}$ & & $\mathrm{F}$ & $\mathrm{M}$ \\
\hline Flying & & 1 & 1 & 1 & 12 & 1 & 21 \\
\hline Foraging & 1 & 1 & 1 & 3 & 4 & 5 & 20 \\
\hline Perching & 1 & 1 & & 2 & 1 & 2 & 9 \\
\hline Watching / Defending & & & & 3 & & & 15 \\
\hline Courtship & & & & & & 1 & 4 \\
\hline Total observations & 2 & 3 & 2 & 9 & 17 & 9 & 69 \\
\hline
\end{tabular}

alpine grasslands foraging from $P$. gentianoides flowers and occasionally from $C$. moranensis flowers. Females were observed flying, feeding, and perching, but never showed territorial behavior (Table 2). Twice during the study period, female individuals were observed above $4200 \mathrm{~m}$ : once a female $S$. platycercus was observed at $4304 \mathrm{~m}$ perching and flying within a patch of $C$. tolucensis in Iztaccihuatl, and another time a female L. clemenciae was recorded in a patch of C. tolucensis in Nevado de Toluca at $4284 \mathrm{~m}$ (representing $5 \%$ of the birds observed in the high alpine habitat). The gender of most $L$. clemenciae individuals could not be determined because males and females were often difficult to distinguish. We observed courtship behaviour four times for S. platycercus, where a male flew up in the air and dove down towards the ground, repeating this maneuver two to three times. On one occasion we observed a female interacting with the male. We did not observe actual mating on any occasion.

\section{Historical records and bird sightings}

\section{Hummingbirds}

The search through bird databases and the literature yielded a record of an unidentified hummingbird species in Pico de Orizaba at $4000 \mathrm{~m}$ in the 1950s (Swan 1952), and four records of hummingbirds above timberland at $4000-4200 \mathrm{~m}$; specifically, $S$. platycercus and L. clemenciae were observed at La Malinche in 1998 (https://ebird.org/view/checklist/S30622948), and S. platycercus was observed at Cerro El Potosí (Guzmán 1998) and at Nevado de Toluca in 1997 (https://ebird.org/averaves/view/checklist/ S2029581). There were no records of the study species above timberline in museum collections and no records of the four bird species used as a control to determine if alpine habitats in Central Mexico had been systematically surveyed.

\section{Plants and glaciers}

According to specimens from MSC and MEXU Herbaria collected during the mid-1900s by Beaman $(\mathrm{n}=1955)$, Iltis $(\mathrm{n}=$ 1029), Matuda ( $\mathrm{n}=26128)$, and Rzedowski $(\mathrm{n}=20139)$, there were populations of $C$. tolucensis between 3800 and 4000 in the slopes of Iztaccíhuatl, where at present there are none (Arredondo-Amezcua, Martén-Rodríguez, Lopezaraiza-Mikel et al., unpublished data). The remaining ornithophilous plant species or those that attract hummingbirds and bees, are only present in the lower elevation alpine grasslands and neighboring forest, both in historical and recent collections; therefore, their distributions do not provide insights into potential elevational changes of hummingbirds.
The available information on the distribution of glaciers at the study sites indicates that the glacier of Iztaccihuatl has retreated to $4 \%$ of its size within the past 150 years (Schneider et al. 2008, Cortés-Ramos and Delgado-Granados 2015), while the glacier of Popocatépetl has disappeared because of recent volcanic activity (Delgado Granados et al. 2007). La Malinche and Nevado de Toluca have not had glaciers since the Late Pleistocene-Holocene glaciations, and the Little Ice Age, respectively (Vázquez-Selem and Heine 2011).

\section{DISCUSSION}

\section{Hummingbird-plant associations}

This study reports the occurrence of four hummingbird species in tropical alpine habitats of the central Mexican mountains above $4000 \mathrm{~m}$ elevation. Previously, the geographic ranges reported for the study species were: $1800-3000 \mathrm{~m}$ for $L$. clemenciae, 1800-3500 m for S. platycercus, 1200-3500 m for Hylocharis leucotis, and 0-2500 for Cynanthus latirostris (Arizmendi and Berlanga 2014). In this study, only Lampornis clemenciae and $S$. platycercus were frequently observed across study sites (Table 2), but all species visited flowers of at least one of two common plant species, Castilleja tolucensis and Penstemon gentianoides, and occasionally fed from $C$. moranensis, a relatively uncommon plant species. Despite the fact that hummingbirds in other habitats visit many flowers of different shapes and colors (e.g., Martén-Rodríguez et al. 2015), the observed hummingbird species did not visit any other flowers at the study sites, possibly because most plant species produce very small amounts of nectar or they lack floral rewards (Arredondo-Amezcua, MarténRodríguez, Lopezaraiza-Mikel et al., unpublished data). The use of various Penstemon and Castilleja flowers by hummingbirds has been reported in montane forest environments in Mexico (Lara-Rodríguez et al. 2012), but C. tolucensis does not occur below timberline. Thus, this is the first report of hummingbird pollination for $C$. tolucensis and the highest elevation at which hummingbirds have been observed feeding on flowers in North America.

Studies of habitat use by hummingbirds in alpine environments should consider measuring the effectiveness of hummingbirds as pollinators of alpine plant species. At the study sites, one species with mixed pollination syndrome, $P$. gentianoides, was visited by both hummingbirds and bumblebees, which coincides with the observed floral visitors to this plant species in high elevation pine and fir forests at La Malinche (Sala-Arcos et al. 2017; ArredondoAmezcua, Martén-Rodríguez, Lopezaraiza-Mikel et al., 
unpublished data). In contrast, Castilleja species were visited exclusively by hummingbirds across all study sites; therefore, alpine populations of $C$. tolucensis and $C$. moranensis do not have at present any alternative pollinators. Castilleja tolucensis is an endemic species of the Mexican alpine grassland listed as vulnerable by the Norma 059 for species at risk (Diario Oficial de la Federación 2015), and three additional species of ornithophilous castillejas inhabit the adjacent subalpine belt (Rodríguez-Jiménez 2005). According to Duffield (1972), selfpollination is uncommon in hummingbird-pollinated castillejas, and this is the case for $C$. tolucensis, which has a reduced set seed when pollinators are excluded (Arredondo-Amezcua, MarténRodríguez, Lopezaraiza-Mikel et al., unpublished data). Therefore, hummingbirds probably play a crucial role in the pollination of castillejas that require biotic vectors to set seed in alpine habitats. Castilleja tolucensis flowers during a short period of time of the year (April-June); thus, it is possible that hummingbirds are moving from lower elevations to use $C$. tolucensis at a time of the year when few other floral resources are available.

Information on the occurrence and ecological drivers of hummingbird elevational migrations in North America is scarce (Boyle 2017); however, various hummingbird species are known to make elevational movements along Mexican mountains mostly linked to food availability because hummingbirds follow the flowering phenology of their floral resources (Ornelas and Arizmendi-Arriaga 1995, Lara 2006). For the hummingbird species reported in this study, elevational migrations have been reported in $C$. latirostris in western Mexico (Ornelas and Arizmendi-Arriaga 1995), in L. clemenciae in the southern U.S. (Williamson 2000), and in southern Mexican populations of $H$. leucotis (Arizmendi et al. 2015). The flowering season of ornithophilous plant species in the study region varies across the elevational gradient, with flowering occurring in spring and summer (April to September) in alpine grassland populations and from summer to winter (July to February) at lower elevation forest sites (Arredondo-Amezcua, personal observations). Therefore, it is possible that the study species use alpine flowers during spring and summer and then move to lower elevations during the coldest months of the year (October to March). The study of temporal changes in hummingbird presence and behavior associated with the availability of different floral resources at different elevations is a subject that deserves further study.

\section{Hummingbird behavior}

The two most frequent hummingbird species in alpine habitats, L. clemenciae and $S$. platycercus were observed during sunny or cloudy weather, throughout the day and at temperatures as low as $3{ }^{\circ} \mathrm{C}$. Feeding at high elevations poses a challenge for hummingbirds because they have to cope with low air temperatures and hypobaric hypoxia. Therefore, hummingbird species from high elevation mountains have particular traits that allow them to live in these environments (Altshuler et al. 2004, Projecto-Garcia et al. 2013). For example, high elevation hummingbird species in the Andes tend to have wing morphologies that increase wing area and stroke amplitude during hovering (Altshuler et al. 2004). Furthermore, physiological traits such as an enhanced ability to use torpor, and the evolution of hemoglobin $(\mathrm{Hb})$ variants that increase $\mathrm{Hb}-\mathrm{O} 2$ affinity allow hummingbirds to deal with low temperatures and low oxygen levels (Projecto-Garcia et al. 2013). Although these morphological and physiological traits have not yet been studied for alpine populations of $C$. latirostris, $H$. leucotis, $L$. clemenciae, and $S$. platycercus, all species are known to have the ability to enter torpor at night (Kruger et al. 1982, Camfield et al. 2013; Andrew, Powers, and Wethington, 2013, unpublished poster, https://www.researchgate.net/publication/265208395_USE_OF_TORPOR_IN_A_HIGH-AND_MID-ELEVATION_HUMMINGBIRD_SPECIES_IN_SOUTHEASTERN_ARIZONA?channel= doi\&linkId=540508db0cf23d9765a6d00f\&showFulltext=true). Additionally, behavioral traits such as a reduction in hovering due to increased perching during feeding may also contribute to preserve energy and reduce oxygen consumption at high elevations (Altshuler and Dudley 2002). This behavior was observed in H. leucotis, L. clemenciae, and S. platycercus at the Iztaccíhuatl volcano (Appendices 3, 5,8). It is yet unknown if the hummingbirds observed in this study are capable of surviving and mating in the alpine grasslands throughout the growing season (April-September) or if they move from the adjacent forest.

There have been no nests of the study species reported in any of the alpine study sites, but courtship behavior was observed in $S$. platycercus at $4000 \mathrm{~m}$ near patches of Penstemon flowers. It would be interesting to determine if hummingbirds use the open grasslands for courtship and mating to increase the visibility of their "dances" and to make use of the abundant floral resources available during the warmer months of the year (JuneSeptember). At present, this may not be a frequent event because females are significantly less frequently present than males in the alpine grasslands and they were rarely observed at the highest elevation sites. It is not clear yet whether females are more difficult to record because they are less conspicuous than males, or if there is gender specific elevational behavior associated with differential energetic demands, tolerance to environmental factors, and use of floral resources between males and female birds. Another possibility is that females have limited access to patches of $C$. tolucensis at the highest elevations because they tend to be well defended by males. These aspects of gender specific behavior and habitat use require further investigation.

\section{Historical evidence for a possible elevational range extension}

The elevational range changes observed for the hummingbird study species may have two contrasting but not mutually exclusive explanations: (a) that hummingbirds were not recorded earlier in alpine habitats in Mexico because of limited sampling by researchers and amateur bird-watchers at high elevation habitats, (b) that hummingbirds have actually expanded their ranges associated with shifts in the elevational distribution of their floral resources because of the recent expansion of habitats suitable for plant growth driven by glacier retreats. Evidence for changes in the elevational distribution of glaciers and ornithophilous plant species suggest a possible elevational range increase in the two most frequent hummingbird study species driven by global climate change. Specifically, the increase in regional temperatures (Aguilar et al. 2005), changes in the extent of the Iztaccíhuatl glacier (Cortés-Ramos and Delgado-Granados 2015), and herbarium records, indicate that $C$. tolucensis, the only ornithophilous plant species at the highest elevations, has 
expanded its elevational range upward. For instance, $C$. tolucensis occurs at $4400 \mathrm{~m}$ at one of the study sites in Iztaccíhuatl, which was covered by glacier at the end of the 19th century (CortésRamos and Delgado-Granados 2015). Furthermore, according to historical herbarium collections, there used to be populations of $C$. tolucensis between 3800 and $4000 \mathrm{~m}$ on the slopes of Iztaccíhuatl, where at present the vegetation is dominated by grassland, thus unsuitable habitat for $C$. tolucensis, a specialist of open gravel/rocky substrates (Almeida-Leñero et al. 2007). Because plant species at the high alpine sites have very small dish or bowl shaped flowers that produce meager amounts of nectar (Arredondo-Amezcua, Martén-Rodríguez, Lopezaraiza-Mikel et al., unpublished data), C. tolucensis can be considered the only resource for hummingbirds in these high-elevation alpine vegetation communities. These data strongly suggest that hummingbirds have expanded their elevational ranges to the highest limit of alpine vegetation within the past century. However, the occurrence of hummingbirds in the lower elevational belt of alpine grasslands may not be a recent event because the low number of hummingbird records in historical museum collections and databases suggests that alpine habitats have been little studied in the past.

\section{CONCLUSIONS}

Cynanthus latirostris, H. leucotis, L. clemenciae, and S. platycercus are widespread species in the Mexican mountains, but habitat loss at lower elevations is a conservation concern (Navarro-Sigüenza et al. 2007). This study shows that hummingbirds in North America have the ability to use floral resources at the highest habitable mountain sites, suggesting alpine environments in Mexico may be important feeding habitats for hummingbirds. Future studies should assess whether these birds are residents of the alpine grassland throughout spring and summer (April to September) or if they make daily movements from adjacent forest patches, as well as potential preadaptations these birds might have to live or forage at such high elevations. Likewise, studies should document plant-pollinator interactions at different elevations to determine potential altitudinal migrations, and the role of hummingbirds in the reproductive success of the ornithophilous plant species along the elevational gradient. Supplementing information gaps on distribution and ecology of these hummingbird species is crucial to better understand their ecological importance and their future role as pollinators in the novel habitats that will become available in high mountains because of glacier retreats.

Responses to this article can be read online at: http://www.ace-eco.org/issues/responses.php/1202

\section{Acknowledgments:}

We thank the staff of Iztaccíhuatl-Popocatépetl Zoquiapan and La Malinche National Parks, and Dr. Victor Steinmann for their support during the development of this research, as well as Dr. Patricia Escalante Pliego for providing access to the database of the National Collection of Birds. We thank Germán Avila for help with field work and Adolfo López Magaña for taking photographs and designing map of the study site. This study is part of the doctoral
}

dissertation of L. Arredondo-Amezcua at Instituto de Ecología. A. C. Financial support was provided by Programa de Apoyo a Proyectos de Investigación e Innovación Universidad Nacional Autónoma de México (PAPIIT IV IV200418, IA208416, IA207618), by CONACyT-Mexico (Projects: Laboratorio Nacional de Análisis y Síntesis Ecológica 271449, 280505, 293701, Sagarpa-CONACyT 291333, Repositorio Institucional 271432 to SMR and MQ, SEP-CONACyT P250996 to MLM, and graduate fellowship 168433/168433 to LAA).

\section{LITERATURE CITED}

Aguilar, E., T. C. Peterson, P. Ramírez Obando, R. Frutos, J. A. Retana, M. Solera, J. Soley, I. González García, R. M. Araujo, M. A. Rosa Santos, V. E. Valle, M. Brunet, L. Aguilar, L. Álvarez, M. Bautista, C. Castañón, L. Herrera, E. Ruano, J. J. Sinay, E. Sánchez, G. I. Hernández Oviedo, F. Obed, J. E. Salgado, J. L. Vázquez, M. Baca, M. Gutiérrez, C. Centella, J. Espinosa, D. Martínez, B. Olmedo, C. E. Ojeda Espinoza, R. Núñez, M. Haylock, H. Benavides, and R. Mayorga. 2005. Changes in precipitation and temperature extremes in Central America and northern South America, 1961-2003. Journal of Geophysical Research 110(D23). http://dx.doi.org/10.1029/2005JD006119

Almeida-Leñero, L., M. Escamilla, J. Giménez de Azcárate, A. González-Trápaga, and A. M. Cleef. 2007. Vegetación alpina de los volcanes Popocatépetl, Iztaccíhuatl y Nevado de Toluca. Pages 179-198 in I. Luna, J. J. Morrone, and D. Espinosa, editors. Biodiversidad de la Faja Volcánica Transmexicana. Universidad Nacional Autónoma de México - Comisión Nacional para el Conocimiento y Uso de la Biodiversidad. México.

Altshuler, D. L., and R. Dudley. 2002. The ecological and evolutionary interface of hummingbird flight physiology. Journal of Experimental Biology 205:2325-2336.

Altshuler, D. L., R. Dudley, and J. A. McGuire. 2004. Resolution of a paradox: hummingbird flight at high elevation does not come without a cost. Proceedings of the National Academy of Sciences of the United States of America 101:17731-17736. http://dx.doi. org/10.1073/pnas.0405260101

Arbeláez-Cortés, E., and A. G. Navarro-Sigüenza. 2013. Molecular evidence of the taxonomic status of western Mexican populations of Phaethornis longirostris (Aves:Trochilidae). Zootaxa 3716:81-97.

Arizmendi, M. C., and H. Berlanga. 2014. Colibríes de México y Norteamérica. Comisión Nacional para el Conocimiento y Uso de la Biodiversidad, Tlalpan, México. http://dx.doi.org/10.5962/ bhl.title. 112129

Arizmendi, M. C., C. I. Rodríguez-Flores, C. A. SoberanesGonzález, and T. S. Schulenberg. 2015. White-eared Hummingbird (Hylocharis leucotis). In T. S. Schulenberg, editor. Neotropical birds online. Cornell Lab of Ornithology, Ithaca, New York, USA. https://doi.org/10.2173/nb.whehum.01

Barrantes, G. 2005. Aves de los páramos de Costa Rica. Pages 521-532 in M. Kappelle, and S. P. Horn, editors. Páramos de Costa Rica. Instituto Nacional de Biodiversidad, Santo Domingo de Heredia, Costa Rica.

Boyle, W. A. 2017. Altitudinal bird migration in North America. Auk 134:443-465 http://dx.doi.org/10.1642/AUK-16-228.1 
Camfield, A. F., W. A. Calder, and L. L. Calder. 2013. Broadtailed Hummingbird (Selasphorus platycercus). In A. F. Poole, editor. The birds of North America. Cornell Lab of Ornithology, Ithaca, New York, USA. https://doi.org/10.2173/bna.16

Cortés-Ramos, J., and H. Delgado-Granados. 2015. Reconstruction of glacier area on Citlaltépetl volcano, 1958 and implications for Mexico's glaciation rates. Geofísica Internacional 54:111-125 http://dx.doi.org/10.1016/j.gi.2015.04.008

Cronk, Q., and I. Ojeda. 2008. Bird-pollinated flowers in an evolutionary and molecular context. Journal of Experimental Botany 59:715-727. http://dx.doi.org/10.1093/jxb/ern009

Del Hoyo, J., N. J. Collar, D. A. Christie, A. Elliott, and L. D. C. Fishpool. 2014. HBW and BirdLife International illustrated checklist of the birds of the world. BirdLife International and Lynx Edicions, Barcelona, Spain.

Delgado Granados, H., P. Julio Miranda, C. Huggel, S. Ortega del Valle, and M. A. Alatorre Ibargüengoitia. 2007. Chronicle of a death foretold: extinction of the small-size tropical glaciers of Popocatépetl volcano (Mexico). Global and Planetary Change 56:13-22. http://dx.doi.org/10.1016/j.gloplacha.2006.07.010

Diario Oficial de la Federación. 2015. Proyecto de Modificación del Anexo Normativo III, Lista de especies en riesgo de la Norma Oficial Mexicana NOM-059-SEMARNAT-2010, Protección ambiental-Especies nativas de México de flora y fauna silvestresCategorías de riesgo y especificaciones para su inclusión, exclusión o cambio-Lista de especies en riesgo, publicada el 30 de diciembre de 2010. Secretaría de Gobernación, México. [online] URL: http://dof.gob.mx/nota detalle.php?codigo $=5420810 \&$ fecha $=21 / 12 / 2015$

Díaz-Valenzuela, R. 2016. Historia Natural, Ecología, y Análisis de la Interacción Planta-Colibrí en un Paisaje Mexicano, Bajo Dos Aproximaciones Teóricas: Escalamiento en Ecología y Redes de Interacciones Complejas. Tesis de doctorado. Universidad de Alicante, Alicante, Spain.

Duffield, W. J. 1972. Pollination ecology of Castilleja in Mount Rainier National Park. Ohio Journal of Science 72:110-114.

Facultad de Ciencias. 2015. Colección Aves. Facultad de Ciencias, Universidad Nacional Autónoma de México. [online] URL: http://uniciencias.fciencias.unam. $\mathrm{mx} /$ busqueda.php?coleccion=aves

Guzmán, V. A. 1998. Distribución altitudinal de la avifauna del cerro El Potosí, Galeana, Nuevo León, México. Thesis. Universidad Autónoma de Nuevo León, Facultad de Ciencias Biológicas. Nuevo León, México.

Healy, S., and W. A. Calder. 2006. Rufus Hummingbird (Selasphorus rufus). In A. F. Poole, editor. The birds of North America. Cornell Lab of Ornithology, Ithaca, New York, USA. https://doi.org/10.2173/bna.53 http://dx.doi.org/10.2173/bna.53

Kruger, K., R. Prinzinger, and K. L. Schuchmann. 1982. Torpor and metabolism in hummingbirds. Comparative Biochemistry and Physiology Part A: Physiology 73:679-689. http://dx.doi. org/10.1016/0300-9629(82)90275-4

Lara, C. 2006. Temporal dynamics of flower use by hummingbirds in a highland temperate forest in Mexico. Ecoscience 13:23-29 http://dx.doi.org/10.2980/1195-6860(2006) 13[23:TDOFUB]2.0.CO;2
Lara-Rodríguez, N., R. Díaz-Valenzuela, V. Martínez-García, E. Mauricio-Lopéz, S. Anaid-Díaz, O. Israel Valle, A. Denisse Fisher-de León, C. Lara, and R. Ortiz-Pulido. 2012. Redes de interacción colibrí-planta del centro-este de México [Hummingbirdplant mutualistic networks in central-eastern Mexico]. Revista Mexicana de Biodiversidad 83:569-577.

Lauer, W., and D. Klaus. 1975. Geological investigations on the timberline of Pico de Orizaba, Mexico. Arctic and Alpine Research 7:315-330. http://dx.doi.org/10.2307/1550176

Martén-Rodríguez, S., M. Quesada, A. Almarales-Castro, M. Lopezaraiza-Mikel, and C. B. Fenster. 2015. A comparison of reproductive strategies between island and mainland Caribbean Gesneriaceae. Journal of Ecology 103:1190-1204. http://dx.doi. org/10.1111/1365-2745.12457

Navarro-Sigüenza, A. G., A. Lira-Noriega, A. T. Peterson, A. Oliveras de I., and A. Gordillo-Martínez. 2007. Diversidad, endemismo y conservación de las aves. Pages 461-484 in I. Luna, J. J. Morrone, and D. Espinosa, editors. Biodiversidad de la Faja Volcánica Transmexicana. Universidad Nacional Autónoma de México, Comisión Nacional para el Conocimiento y Uso de la Biodiversidad, México.

Ornelas, J. F., and M. C. Arizmendi-Arriaga. 1995. Altitudinal migration: implications for conservation of avian Neotropical migrants in western Mexico. Pages 98-112 in M. H. Wilson and S. A. Sader, editors. Conservation of Neotropical migratory birds in Mexico. Maine Agricultural and Forest Experiment Station, Orono, Maine, USA.

Parque Nacional Izta-Popo. 2015. Aves del Parque Nacional IztaPopo. Guía de campo. Secretaría de Medio Ambiente y Recursos Naturales, Comisión Nacional de Áreas Naturales Protegidas, Comisión Nacional para el Conocimiento y Uso de la Biodiversidad, México.

Pérez, G., C. Lara, M. Signoret-Poillon, and J. A. Viccon-Pale. 2012. Evaluación del uso de señales visuales y de localización por el colibrí cola-ancha (Selasphorus platycercus) al visitar flores de Penstemon roseus. Revista Mexicana de Biodiversidad 83:144-151.

Projecto-Garcia, J., C. Natarajan, H. Moriyama, R. E. Weber, A. Fago, Z. A. Cheviron, R. Dudley, J. A. McGuire, C. C. Witt, and J. F. Storz. 2013. Repeated elevational transitions in hemoglobin function during the evolution of Andean hummingbirds Proceedings of the National Academy of Sciences 110:20669-20674. http://dx.doi.org/10.1073/pnas. 1315456110

Ramírez-Amezcua, Y., V. W. Steinmann, E. Ruiz-Sánchez, and O. R. Rojas-Soto. 2016. Mexican alpine plants in the face of global warming: potential extinction within a specialized assemblage of narrow endemics. Biodiversity and Conservation 25:865-885. http://dx.doi.org/10.1007/s10531-016-1094-x

Rodríguez-Jiménez. 2005. Plantaginaceae. Pages in G. C. Rzedowski and J. Rzedowski editors. Flora fanerogámica del Valle de México. Instituto de Ecología A.C., Comisión Nacional para el Conocimiento y Uso de la Biodiversidad, México.

Rzedowski, J. 2006. Vegetación de México. First digital edition. Edición digital, Comisión Nacional para el Conocimiento y Uso de la Biodiversidad, México. 
Sala-Arcos, L., C. Lara, and J. F. Ornelas. 2017. Reproductive biology and nectar secretion dynamics of Penstemon gentianoides (Plantaginaceae): a perennial herb with a mixed pollination system? PeerJ 5:e3636 http://dx.doi.org/10.7717/peerj.3636

Salamanca-Reyes, J. R., J. Botia-Becerra, and A. Ardila-Vega. 2008. Aves del Páramo del Siscunsí. Asociación para la investigación y Conservación de la Vida Silvestre Neotropical, Colombia.

Schneider, D., H. Delgado Granados, C. Huggel, and A. Kääb. 2008. Assessing lahars from ice-capped volcanoes using ASTER satellite data, the SRTM DTM and two different flow models: case study on Iztaccíhuatl (Central Mexico). Natural Hazards and Earth System Science 8:559-571. http://dx.doi.org/10.5194/ nhess-8-559-2008

Schondube, J. E., S. Contreras-Martínez, I. Ruan-Tejeda, W. A. Calder, and C. E. Santana. 2004. Migratory patterns of the Rufous Hummingbird in western Mexico. Pages 80-95 in G. P. Nabhan, editor. Conserving migratory pollinators and nectar corridors in Western North America. The University of Arizona Press, The Arizona-Sonora Desert Museum, Tuscon, Arizona.

Schuchmann, K. L. 1999. Family Trochilidae (Hummingbirds). Pages 468-535 in J. del Hoyo, A. Elliott, and J. Sargatal, editors. Handbook of birds of the World, Volume 5: Barn-owls to Hummingbirds. Lynx Edicions. Barcelona, Spain.

Swan, L. W. 1952. Some environmental conditions influencing life at high altitudes. Ecology 33:109-111. http://dx.doi. org/10.2307/1931257

Ugalde-Lezama, S., J. L. Alcántara-Carbajal, J. I. ValdezHernández, G. Ramírez-Valverde, J. Velázquez-Mendoza, and L. A. Tarango-Arámbula. 2010. Riqueza, abundancia y diversidad de aves en un bosque templado con diferentes condiciones de perturbación. Agrociencia 44:159-169.

Unidad de Informática para la Biodiversidad. 2007. Aves. Universidad Nacional Autónoma de México, Mexico City, Mexico. [online] URL: http://unibio.unam.mx/collections/ specimens/urn/IBUNAM:CNAV:AV?f=Trochilidae

Vázquez-Selem, L., and K. Heine. 2011. Late quaternary glaciation in Mexico. Developments in Quaternary Science 15:849-861. http://dx.doi.org/10.1016/B978-0-444-53447-7.00061-1

Williamson, S. L. 2000. Blue-throated Hummingbird (Lampornis clemenciae). In A. F. Poole and F. B. Gill, editor. The birds of North America. Cornell Lab of Ornithology, Ithaca, New York, USA. https://doi.org/10.2173/bna.531 
Appendix 1. Geographic locations and descriptions of nine alpine study sites located in four volcanoes of Central Mexico. Observations were conducted at patches of three plant species that hummingbirds visited during 2014-2017, including Penstemon gentianoides, Castilleja moranensis, and C. tolucensis.

\begin{tabular}{|c|c|c|c|c|c|c|}
\hline Site & Volcano & $\begin{array}{l}\text { Coordinates / elevation (m) / } \\
\text { locality }\end{array}$ & Site description & $\begin{array}{l}\text { Plant species / } \\
\mathrm{N} \text { of patches }\end{array}$ & $\begin{array}{l}\mathrm{N} \\
\text { hours }\end{array}$ & Sampling Dates \\
\hline Mal 1 & $\begin{array}{l}\text { La Malinche } \\
4461 \mathrm{~m}\end{array}$ & $\begin{array}{l}19^{\circ} 14^{\prime} 25.4 " \mathrm{~N}, 98^{\circ} 01 ' 56.3^{\prime \prime} \mathrm{W} / \\
3929 \text { / North slope. }\end{array}$ & $\begin{array}{l}\text { Slope with shrubs and tussock } \\
\text { grasses. }\end{array}$ & $\begin{array}{l}P . \text { gentianoides / } \\
\mathrm{N}=2\end{array}$ & 2 & June 2016 \\
\hline Mal 2 & & $\begin{array}{l}19^{\circ} 14^{\prime} 6.1^{\prime \prime} \mathrm{N}, 98^{\circ} 02^{\prime} 1.7^{\prime \prime} \mathrm{W} / 4174 \\
\text { / Texcalco cave. }\end{array}$ & $\begin{array}{l}\text { Gravelly-rocky slope cushion- } \\
\text { shaped plants. }\end{array}$ & $\begin{array}{l}\text { C. tolucensis / } \\
\mathrm{N}=2\end{array}$ & 10 & April-June 2016 \\
\hline NT 1 & $\begin{array}{l}\text { Nevado de } \\
\text { Toluca } \\
4690 \mathrm{~m}\end{array}$ & $\begin{array}{l}19^{\circ} 06157.3^{\prime \prime} \mathrm{N}, 99^{\circ} 44^{\prime} 48.8^{\prime \prime} \mathrm{W} / \\
4197 \text { / trail to the Moon lake. }\end{array}$ & $\begin{array}{l}\text { Gravelly-rocky slope, cushion- } \\
\text { shaped plants. }\end{array}$ & $\begin{array}{l}\text { C. tolucensis / } \\
\mathrm{N}=2\end{array}$ & 4 & June 2017 \\
\hline NT 2 & & $\begin{array}{l}19^{\circ} 06^{\prime} 16.0^{\prime \prime} \mathrm{N}, 99^{\circ} 45^{\prime} 17.4^{\prime \prime} \mathrm{W} / \\
4284 \text { / trail to the summit. }\end{array}$ & $\begin{array}{l}\text { Gravelly-rocky slope cushion- } \\
\text { shaped plants. }\end{array}$ & $\begin{array}{l}\text { C. tolucensis / } \\
\mathrm{N}=4\end{array}$ & 10 & April, June 2017 \\
\hline Izta 1 & $\begin{array}{l}\text { Iztaccíhuatl } \\
5230 \mathrm{~m}\end{array}$ & $\begin{array}{l}19^{\circ} 07^{\prime} 4.9^{\prime \prime N}, 98^{\circ} 38^{\prime} 48.6^{\prime \prime} \mathrm{W} / \\
3903 \text { / Altzomoni Hill. }\end{array}$ & $\begin{array}{l}\text { Slope with shrubs and tussock } \\
\text { grasses. }\end{array}$ & $\begin{array}{l}P . \text { gentianoides / } \\
\mathrm{N}=4 \\
C . \text { moranensis / } \\
\mathrm{N}=2\end{array}$ & 34 & $\begin{array}{l}\text { Aug-Sept 2014; } \\
\text { July-Sept 2016; } \\
\text { July } 2017\end{array}$ \\
\hline Izta 2 & & $\begin{array}{l}19^{\circ} 08^{\prime} 34.1^{\prime \prime N}, 98^{\circ} 38^{\prime} 46.8^{\prime \prime} \mathrm{W} / \\
3955 \text { / Tiburón trail. }\end{array}$ & $\begin{array}{l}\text { Slope with shrubs and tussock } \\
\text { grasses. }\end{array}$ & $\begin{array}{l}P . \text { gentianoides / } \\
\mathrm{N}=3\end{array}$ & 3 & $\begin{array}{l}\text { July 2016; } \\
\text { July, Sept } 2017\end{array}$ \\
\hline Izta 3 & & $\begin{array}{l}19^{\circ} 08^{\prime} 35.7^{\prime \prime N}, 98^{\circ} 38^{\prime} 21.1 " \mathrm{~W} / \\
4304 \text { / Segundo portillo. }\end{array}$ & $\begin{array}{l}\text { Gravelly-rocky slope cushion- } \\
\text { shaped plants. }\end{array}$ & $\begin{array}{l}\text { C. tolucensis / } \\
\mathrm{N}=1\end{array}$ & 5 & $\begin{array}{l}\text { May, June 2016; } \\
\text { July } 2017\end{array}$ \\
\hline Izta 4 & & $\begin{array}{l}19^{\circ} 08^{\prime} 52.9^{\prime \prime} \mathrm{N}, 98^{\circ} 38^{\prime} 18.4^{\prime \prime} \mathrm{W} / \\
4428 \text { / Castillejas' wetland. }\end{array}$ & $\begin{array}{l}\text { Rocky wetland slope cushion- } \\
\text { shaped plants. }\end{array}$ & $\begin{array}{l}\text { C. tolucensis / } \\
\mathrm{N}=4\end{array}$ & 6 & $\begin{array}{l}\text { May-June 2016; } \\
\text { April, July } 2017\end{array}$ \\
\hline Popo 1 & $\begin{array}{l}\text { Popocatépetl } \\
5465 \mathrm{~m}\end{array}$ & $\begin{array}{l}19^{\circ} 03^{\prime 2} 23.4^{\prime \prime N}, 98^{\circ} 38^{\prime} 12.1^{\prime \prime W} / \\
4017 \text { / Vicinity of Tlamacas } \\
\text { refuge. }\end{array}$ & $\begin{array}{l}\text { Dry sandy slope with shrubs and } \\
\text { tussock grasses. }\end{array}$ & $\begin{array}{l}P . \text { gentianoides / } \\
\mathrm{N}=2\end{array}$ & 6 & July 2017 \\
\hline
\end{tabular}

